\title{
Antiproliferative Effect of Secang Heartwood Ethanolic Extract (Caesalpinia sappan L.) on HER2-Positive Breast Cancer Cells
}

\author{
Rahmawaty Rachmady, Laely Muntafiah, Fahmi Rosyadi, Imroatus Sholihah, \\ Sri Handayani, Riris Istighfari Jenie ${ }^{*}$
}

Cancer Chemoprevention Research Center, Faculty of Pharmacy, Universitas Gadjah Mada, Yogyakarta, Indonesia

\begin{abstract}
Human Epidermal Growth Factor Receptor 2 (HER2) plays critical role in the initiation of breast cancer cell proliferation. Inhibition of HER2 overexpression is a promising strategy in the treatment of breast cancer. One of the potential natural substances that possess cytotoxic in cancer cells is Secang (Caesalpinia sappan L.). Ethanolic extract of secang heartwood containing brazilein and brazilin shows cytotoxic effect on various cancer cells. Thus this research aims to determine the proliferative inhibition activity of secang heartwood ethanolic extract (SEE) through HER2 expression on MCF-7/HER2 positive. Cytotoxic activity of SEE on MCF-7/HER2 positive cells was observed by MTT assay, meanwhile the inhibition activity of HER2 on MCF-7/HER2 cells was determined by immunofluoresence assay. Furthermore, to confirm the possible mechanism of brazilein and brazilin for its cytotoxic activity was studied through molecular docking using PLANTS software. Based on this study, SEE exhibited cytotoxic effect on MCF-7/HER2 positive cells with IC 50 value of 25 $\mu \mathrm{g} / \mathrm{ml}$, and EES also inhibited HER2 expression, indicated that the antiproliferative effect of SEE was possible through the inhibition of HER2. Docking score of brazilein, brazilin, and native ligand on HER2 were $-77 ;-73 ;-120$ respectively, showed the affinity of brazilein in HER2 was lower than affinity of native ligand, but they had specific amino acid to interaction. Hence, SEE can be developed as one of promising chemopreventive agent from natural products.
\end{abstract}

Keywords: Caesalpinia sappan L., cytotoxic, immunofluorescence, molecular docking, MCF7/HER2 cells

\section{INTRODUCTION}

Human Epidermal Growth Factor Receptor 2 (HER2) protein is known to inhibit the anti-apoptotic protein, causing proliferation of breast cancer cells continuously (Siddiqa, et al., 2008). At least, there are $15-20 \%$ of breast cancer patients occur show HER2 overexpression (Perou, et al., 2006). HER2 overexpression causes breast cancer cell growth becomes uncontrolled and abnormal (Laskin and Sandler, 2004). Therefore in present research, targeting HER2 protein become one of focuses in anticancer drugs finding. One of the local natural products that have been studied and showed potency as a cancer chemoprevention agent is a Secang (Caesalpinia sappan L.). Previous studies reported that the active compounds in the Secang has possessed cytotoxic effect on MCF7 breast cancer cells with $\mathrm{IC}_{50}$ value of 37 $\mu \mathrm{g} / \mathrm{mL}$ (Khamsita, 2012). However, possible molecular mechanism which responsible for cytotoxic effect on breast cancer from secang remains unclear. Thus, this study aims to explore secang as antiproliferative agent on breast cancer cells through inhibition of HER2 expression.

\footnotetext{
$\overline{* \text { Corresponding author e-mail : ririsjenie@ gmail.com }}$
} 


\section{MATERIALS AND METHODS}

\section{Sample Preparation and Extraction}

Secang heartwood were collected from Yogyakarta, Indonesia and determined in Departement of Pharmaceutical Biology, Faculty of Pharmacy UGM.

Dried powder was extracted by maceration for 5 days with $70 \%$ ethanol and continued by remaceration for the next 3 days. Collected filtrate were concentrated using rotary evaporator to get viscous extract.

\section{Cell Culture}

MCF-7/HER2 cells were collection of Cancer Chemoprevention Research Center (CCRC), Faculty of Pharmacy, UGM, Indonesia. The cells were kindly given from The Cell Resource Center for Biomedical Research, Institute of Development, Aging and Canccer, Tohoku University and The Japanese Center Research Resources Bank. Cells were cultured in Dulbecco's Modified Eagle Medium (DMEM) high glucose (Sigma) supplemented with 10\% FBS (Sigma), HEPES, sodium bicarbonate, $1.5 \%$ Penicillin-Streptomycin and $0.5 \%$ Fungizone (Gibco) and maintained with hygromycin (Gibco). Cells were incubated in $37^{\circ} \mathrm{C}$ incubator with $5 \% \mathrm{CO}_{2}$.

\section{Cytotoxic assay}

MTT assay was used to determine the cytotoxic effect of secang heartwood ethanolic extract (SEE) on MCF-7/HER2 cells. Cells were distributed to 96-well plate with the density of $5 \times 10^{3}$ cells/well and incubated in $37^{\circ} \mathrm{C}$ with $5 \% \quad \mathrm{CO}_{2}$ for 24 hours. A serial concentration of SEE was diluted on DMEM with DMSO (Sigma) as cosolvent to determine $\mathrm{IC}_{50}$ value of EES. After 24 hours of incubation, 3-(4,5-di methyl thiazol -2-yl)-2,5diphenyl tetrazolium bromide (MTT) (Sigma) was added and followed by 4 hours incubation to form formazan crystal before diluted with $10 \% \mathrm{v} / \mathrm{v}$ SDS in $0.1 \mathrm{~N}$ HCL (Merck) as stopper reagent. Plate was kept with protection from light for overnight. The intensity of the color formed was measured by ELISA reader at $\lambda$ $595 \mathrm{~nm}$ using ELISA reader (Bio-Rad). IC $_{50}$ value, a concentration which inhibit $50 \%$ cell population, was calculated from linear regression of $\log$ concentration and cells viability.

\section{Immunofluorescence Assay}

HER2 expression was observed by immunofluorescence assay. Confluent MCF7/HER2 cells were harvested with trypsinEDTA and distributed with a density of $5 \times 10^{4}$ cells/well in 24-wellplate and incubated for 24 $\mathrm{h}$ at $37^{\circ} \mathrm{C}, 5 \% \mathrm{CO}_{2}$. The cells were treated with sample and incubated again. After 15 hours, cell were fixed by $70 \%$ ethanol and incubated for $15 \mathrm{~min}$ at room temperature. After rinsed with PBS, cells were incubated with blocking serum $1 \% \mathrm{BSA}$ for $30 \mathrm{~min}$ at room temperature. Then, cells were incubated with primary antibody (HER2) for 1 hour at room temperature. After rinsed with PBS, cells were incubated with secondary antibody conjugated by FITC for 1 hour at room temperature in the dark. Then, cell were added by DAPI solution and incubated for $10 \mathrm{~min}$ at room temperature in the dark. After rinsed with PBS, cell were added with mounting solution (fluoromount), put on slide glass, and store at $4^{\circ} \mathrm{C}$. The protein expressions were observed under fluorescence microscope.

\section{Molecular Docking}

In silico study by molecular docking was conducted to examine the affinity of certain ligand to its docking site by evaluating drugreceptor binding energy. Evaluation of the interaction between a molecule and its docking protein involved in particular signal transduction may represent its potential biological activity and allow us to determine the possible mechanism of action. In this study, the docking of brazilin and brazielin as major compound in SEE to HER2 ATP Binding Site was observed, using lapatinib as a comparation. Ligands preparation were done by using Marvin Sketch. 


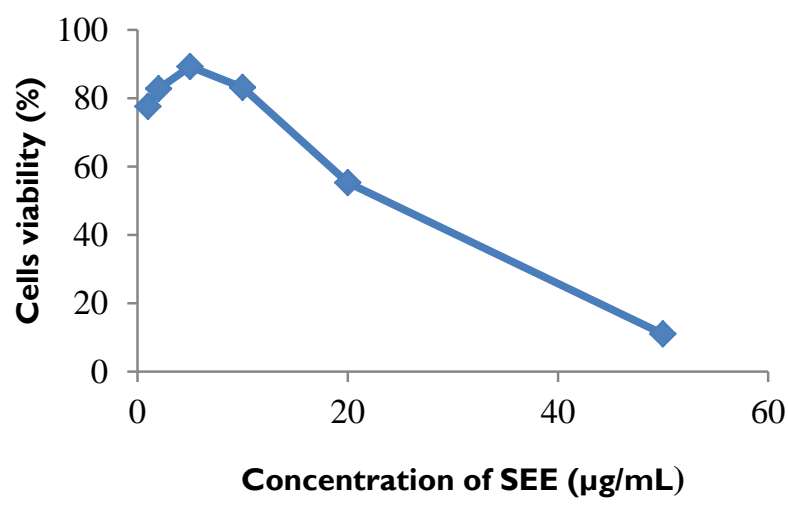

Figure I. Cytotoxic effect of SEE on MCF7/HER2 cells. Briefly $5 \times 10^{3}$ cells/well of MCF-7/HER2 cells were seeded in 96 well-plate and incubated for $24 \mathrm{~h}$, then treated with SEE. Cells viability was determined by using MTT assay as described in the methods. Cell viability profile after treatment of SEE for $24 \mathrm{~h}$ on MCF-7/HER2 cells.

The structure of HER2 protein (3PPO) complex was taken from Protein Data Bank (PDB) (www.rcsb.org). Protein preparation was done by using YASARA. Molecular docking was conducted by using PLANTS (ProteinLigand Ant System) Software, giving $\Delta \mathrm{G}$ as docking score result.

\section{RESULTS AND DISCUSSION}

\section{Cytotoxic Effect of SEE on MCF-7/HER2 Cells}

MTT assay was used to evaluate the cytotoxic effect of SEE on breast cancer with HER2 protein overexpression. With $\mathrm{IC}_{50}$ value as parameter. Cytotoxic effect of SEE was observed after $24 \mathrm{~h}$ of treatment. Single treatment of $\mathrm{K} \mathrm{PGV-0}$ for $24 \mathrm{~h}$ induced morphological changes at dose dependent manner as seen in Fig. 2. Based on MTT assay, SEE was potently inhibited cells with IC50 value of $25 \mu \mathrm{g} / \mathrm{mL}$ on MCF-7/HER2 breast cancer cells.

This result added the potency of SEE as antiproliferative agent towards cancer cells. Previously, single treatment of SEE showed cytotoxic effect on MCF-7 breast cancer cells with $\mathrm{IC}_{50}$ value of $37 \mu \mathrm{g} / \mathrm{mL}$ (Khamsita, et al., 2012). The data is interesting as SEE possessed more cytotoxic effect on breast cancer cells with HER2 overexpression than wild type one. Hence, the possibility of cell proliferation with modulation of HER2 protein was investigated through immunofluorescence assay.

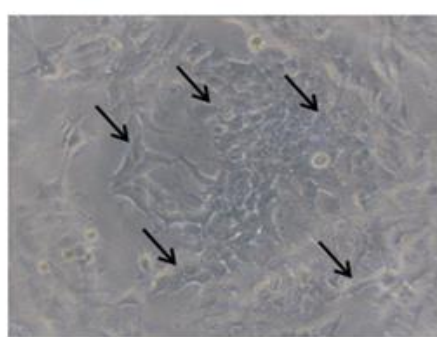

(A)

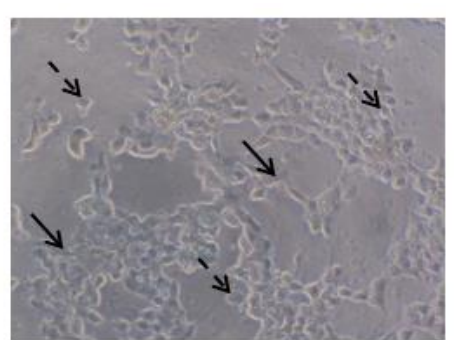

(B)

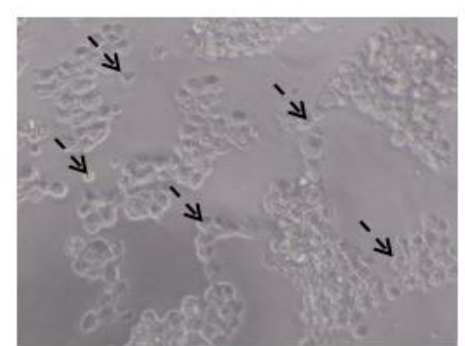

(C)

Figure 2. Cytotoxic activity of SEE on MCF-7/HER2 breast cancer cells. Cells morphological with or without SEE treatment after $24 \mathrm{~h}$ incubation. Cells were observed under inverted microscope and documented with 400x magnification. (A) cell control, (B) SEE $10 \mu \mathrm{g} / \mathrm{mL}$, and (C) SEE $50 \mu \mathrm{g} / \mathrm{mL}$. Alive cells were marked by arrow $(\rightarrow)$ while cells woth morphological change were shown with $(\rightarrow)$. 


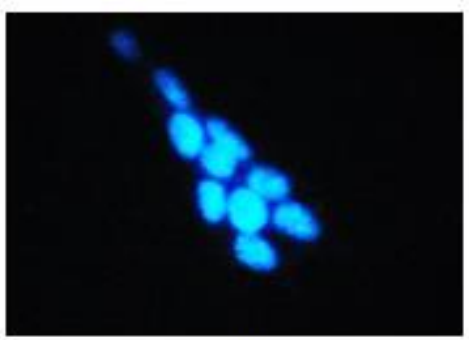

(A)

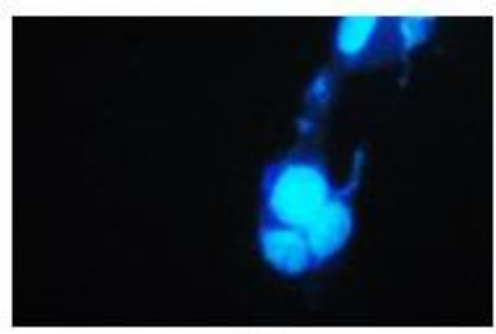

(C)

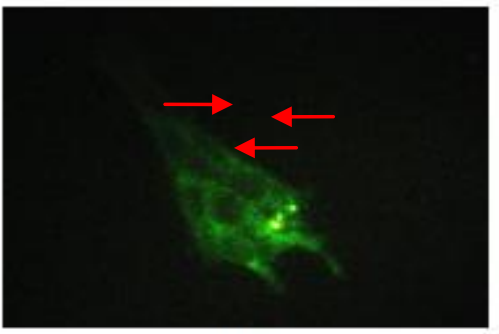

(B)

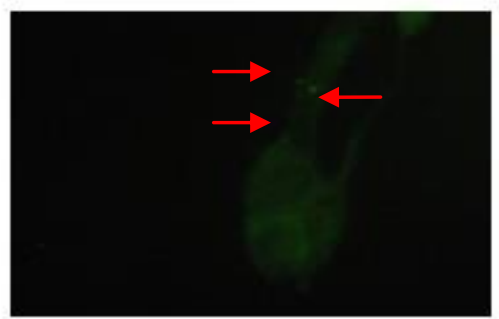

(D)

Figure 3. The expression of HER2 protein by immunofluorescence after treatment with SEE. Cells were treated with SEE for $24 \mathrm{~h}$ before immunofluorescence as described on method. Cells were observed under fluorescent microscope with 400x magnification. On the picture (A) DAPI control, (B) Alexa 488 anti-mouse control, (C) SEE with concentration of $12,5 \mu \mathrm{g} / \mathrm{mL}$ in DAPI staining, (D) SEE with concentration of $12,5 \mu \mathrm{g} / \mathrm{mL}$ with Alexa 488 anti-mouse staining. The changes in expression was marked with red arrow $\rightarrow$

Based on the experiment in MCF7/HER2 cells, single treatment with SEE with concentration of $12.5 \mu \mathrm{g} / \mathrm{mL}$ reduced the expression of HER2 protein compared to control group (Fig. 3). The result was correlated to the cytotoxic effect of SEE, indicated that there was possibility that SEE played a critical role in HER2 protein expression. The result was supported by previous study done by Laksmiani, et al (2014) who did interaction between brazilein as major compound in SEE with HER2 receptor by molecular docking. Brazilein was able to interact with HER2 in ATP-binding site in hydrophobic region with amino acid residue Tyr 91, which had similar interaction with native ligand. Brazilein was also reported to inhibit $\mathrm{nfkB}_{\mathrm{B}}$, one of transcription factor of HER2 that caused inhibition of several protein that regulate cells proliferation (Konkimalla, et al., 2009; Hsieh, et al., 2013). Hence, SEE possessed cytotoxic effect on breast cancer though inhibition on HER2 protein.

\section{ACKNOWLEDGMENT}

This study was financially supported by Research Grant from Ministry of Research , Technology, and Higher Education of the Republic of Indonesia through the scheme of Program Kreativitas Mahasiswa Penelitian (PKM-P) 2014.

\section{REFERENCES}

Dolinsky, C, 2002, Breast Cancer: The Basic. Abramson Cancer Center of the University of Pennsylvania, http://www.oncolink.org.

Eccles, S.A. , 200I, C-erb2/HER2/neu in The Role of Breast Cancer Progression and Metastasis, J. Mammary Gland Biol. Neoplasia, 6(4), 393-406.

Foster, J.S., Henley, D.C., Ahamed, S. and Wimalasena, J., 200I, Estrogens and Cell Cycle Regulation in Breast Cancer., Trends Endocrinol. Metab., 12 (7), 320-327. 
Gibbs, J.B., 2000, Anticancer Drug Targets: Growth Factor and Growth Factor Signaling, J. Clin. Invest., I05(I), 9-I3.

Hsieh, C.Y., Tsai, P.C., Chu, C.L., Chang, F.-R., Chang, L.S., Wu, Y.C., et al., 2013, Brazilein Suppresses Migration and Invasion of MDA-MB-23I Breast Cancer Cells, Chem. Biol. Interact., 204(2), I05-II5.

Khamsita, R., Hermawan, A.,, Putri, D. D. P. and Meiyanto, E. 2012. Ethanolic Extract of Secang (Caesalpinia sappan L.) Wood Performs as Chemosensitizing Agent Through Apoptotic Induction on Breast Cancer MCF-7 Cells, Indones. J. Cancer Chemoprevent., 3(3), 445-450.

Konkimalla, McCubrey, J.A. and Efferth, T., 2009, The Role of Downstream Signaling Pathways of the Epidermal Growth Factor Receptor for Artesunate's Activity in Cancer Cells, Curr. Cancer Drug Targets., 9(I), 72-80.

Laksmiani, N., L., Susidarti, R., A. and Meiyanto, E., 2014, Brazilein Increases The Sensitivity of Doxorubicin On MCF-7 Resistant Doxorubicin (MCF-7/Dox) Cells Through Inhibition of HER-2 Activation, Int. J. Pharm. Pharm. Sci., 7(2), 525-528.

Laskin, J.J. and Sandler, A.B., 2004, Epidermal Growth Factor Receptor: A Promising
Target in Solid Tumors, Cancer Treat. Rev., 30, I-I7.

Carey, L.A., Perou, C.M., Livasy, C.A., Dressler, L.G., Cowan, D., Conway, K., et al., 2006, Breast Cancer Subtypes, and Survival in the Carolina Breast Cancer Study, JAMA, 295(2I), 2492 - 2502.

Siddiqa, A., Long, L.M., Li, L., Marciniak, R.A. and Kazhdan, I., 2008, Expression of HER-2 in MCF-7 Breast Cancer Cells Modulates Anti-Apoptotic Reseptors Survivin and $\mathrm{Bcl}-2$ via the Extracellular Signal-Related Kinase (ERK) and Phosphoinositide-3 Kinase (PI3K) Signalling Pathways, BMC Cancer, 8, 129.

Yen, C.T., Nakagawa-Goto, K., Hwang, T.L., Wu, P.C., Morris-Natschke, S.L., Lai, W.C., et al., 2010, Antitumor Agents. 27I. Total Synthesis and Evaluation of Brazilein and Analogs as Antiinflammatory and Cytotoxic Agents, Bioorg. Med. Chem. Lett., 20(3), I0371039

Zhong, X., Wu, B., Pan, Y.J. and Zheng, S., 2009, Brazilein Inhibits Survivin Protein and mRNA Expression and induces apoptosis in HepG2 Hepatocellular Carcinoma Cells, Neoplasma, 56(5), 387-92. 